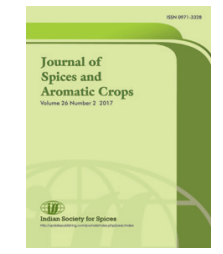

\title{
Bacillus subtilis, a potential biocontrol agent for the management of coriander wilt
}

S Aswathi \& C Ushamalini*

Department of Plant Pathology, Tamil Nadu Agricultural University, Coimbatore-641 003, Tamil Nadu.

*E-mail: ushackadir@yahoo.co.in

Received 09 March 2017; Revised 06 June 2017; Accepted 23 October 2017

\begin{abstract}
Coriander is an important spice crop affected by wilt caused by Fusarium oxysporum f. sp. corianderii. Two trials were conducted to evaluate the efficacy of Bacillus subtilis for the management of wilt under glass house condition. The results of the trials indicated that, among the various treatments, seed treatment with talc formulation of Bacillus subtilis $\left(10 \mathrm{~g} \mathrm{~kg}^{-1}\right.$ of seed) along with soil application $\left(2.5 \mathrm{~kg} \mathrm{ha}^{-1}\right)$ as basal and top dressing at 30 and 45 days after sowing was effective in reducing the wilt incidence $(14.59 \%)$ compared to control $(32.68 \%)$.
\end{abstract}

Keywords: coriander, wilt, Fusarium oxysporum f. sp. corianderii, biocontrol, Bacillus subtilis

Coriander (Coriandrum sativum L.) one of the important seed spices belonging to the family Apiaceae is mainly cultivated in Rajasthan, Gujarat, Haryana, Punjab, Madhya Pradesh, Uttar Pradesh, Andhra Pradesh, Karnataka and Tamil Nadu.

Pests and diseases are the major constraints in the production of coriander. Coriander cultivation is affected by several diseases like wilt caused by Fusarium oxysporum f.sp. corianderii (Srivastava 1972), stem gall caused by Protomyces macrosporus (Das 1971), grain mould caused by Helminthosporium spp., Fusarium spp., Curvularia spp. and Alternaria spp. (Rajan et al. 1990) and powdery mildew (Erisyphe polygoni).

The occurrence of coriander wilt has been reported from few parts of India viz., Gwalior and Guna districts of Madhya Pradesh, Kota division of Rajasthan (ICAR report 1953) and
Coimbatore district of Tamil Nadu (Prakasam et al. 1987). Among the diseases, wilt caused by Fusarium oxysporum f. sp. corianderii causes a yield loss of $10-60 \%$ (Prakasam et al. 1987). The infected plant exhibits drooping of leaves, the characteristic symptoms along with vascular discolouration.

It has been found that members of the genus Bacillus has been successfully used in controlling plant diseases in a wide variety of crops including rice (Peng et al. 2014), wheat (Liu et al. 2009), potato (Balabel et al. 2013), brinjal (Saha et al. 2012), and cucumber (Huang et al. 2012).

The present study was conducted to evaluate the effectiveness of Bacillus subtilis for the management of coriander wilt under glass house condition. 
The wilt pathogen Fusarium oxyspoum f.sp. corianderii was isolated from infected plants and the different strains of Bacillus subtilis were isolated from rhizosphere of healthy coriander plants by following serial dilution technique in Nutrient Agar medium and some Bacillus strains were also obtained from the Department of Plant Pathology, Tamil Nadu Agricultural University. The isolated Bacillus spp. were identified based on morphological characters and by molecular methods (sequencing). The Bacillus strains were tested for their inhibitory activity on mycelial growth of the pathogen by dual plate technique (Dennis $\&$ Webster 1971). The effective strain of B. subtilis (VB1) was selected based on their inhibitory activity on mycelial growth of the pathogen (data not presented).

A loopful of effective B. subtilis (VB1) was inoculated into sterilized Nutrient agar broth and incubated in a rotary shaker at $150 \mathrm{rpm}$ for $72 \mathrm{~h}$ at room temperature $\left(28 \pm 2^{\circ} \mathrm{C}\right)$. After $72 \mathrm{~h}, 400 \mathrm{~mL}$ of bacterial broth suspension $(9 \times$ $10^{8} \mathrm{cfu} \mathrm{mL}^{-1}$ ) was mixed with $1 \mathrm{~kg}$ of the talc powder (carrier material), $15 \mathrm{~g}$ calcium carbonate (to adjust $\mathrm{pH}$ to neutral) and $5 \mathrm{~g}$ CMC (adhesive) under sterile conditions. The mixture was shade dried and packed in polythene bags and kept at room temperature condition (Vidhyasekaran \& Muthamilan 1995).

During Kharif \& Rabi 2015, two glass house trials were conducted at TNAU orchard to test the efficacy of $B$. subtilis strain for the management of wilt disease. The virulent isolate (Isolate from Mettupalayam - Foc 1) of wilt pathogen was mass multiplied in sand maize medium and it was mixed with sterilized potting mixture at the ratio of $5 \%(\mathrm{w} / \mathrm{w})$. Surface sterilized coriander seeds were treated with bacterial antagonist formulations ( $B$. subtilis @ $10 \mathrm{~g} \mathrm{~kg}^{-1}$ of seeds, Pseudomonas fluorescens $@ 10 \mathrm{~g} \mathrm{~kg}^{-1}$ of seeds) and sown in pathogen inoculated $30 \mathrm{~cm}$ diameter pots. Ten seeds (variety: $\mathrm{CO} 4$ ) were sown pot $^{-1}$ and three replications per treatment were maintained. Observations were recorded on germination percentage, plant height, disease incidence and seed yield.
The experiment was conducted in completely randomized block design and replicated thrice. The incidence of wilt was assessed using the formula:

Per cent Disease Incidence $=[$ Number of infected plants / Total number of plants] $\times 100$

The results of glass house trial conducted during Kharif 2015 revealed that, the germination percentage ranged from $74 \%$ to $89 \%$. The observation on growth parameter i.e., plant height was recorded on 60 DAS, which ranged from 46 to $53 \mathrm{~cm}$.

The disease incidence was recorded on 45 and 60 days after sowing (DAS). The lowest wilt incidence $(16.33 \%)$ was recorded in seed treatment combined with soil application of $B$. subtilis (VB1), while in control the incidence was $35.56 \%$ (Table 1).

The results of the Rabi trial indicated that, the lowest wilt incidence $(12.85 \%)$ was recorded in seed treatment combined with soil application of B.subtilis (VB1), while in control it was $29.81 \%$ (Table 2).

The pooled mean of two trials indicated that, seed treatment with talc formulation@10 g $\mathrm{kg}^{-1}$ of seed and soil application @2.5 kg ha-1 significantly reduced the wilt incidence $(14.59 \%)$, compared with control $(32.68 \%)$, followed by seed treatment and soil application of $P$. fluorescens $(16.24 \%)$. This treatment also recorded grain yield of $85.97 \mathrm{~g} \mathrm{pot}^{-1}$ compared to control which recorded $48.67 \mathrm{~g} \mathrm{pot}^{-1}$ (Table 3).

In the glass house studies, application of $B$. subtilis as seed treatment $\left(10 \mathrm{~g} \mathrm{~kg}^{-1}\right)$ and soil application $\left(2.5 \mathrm{~kg} \mathrm{ha}^{-1}\right)$ as basal and top dressing at 30 and 45 DAS, was found to be effective in reducing wilt incidence in coriander under glass house condition.

Ashwini \& Srividya (2014) studied the potentiality of B.subtilis as biocontrol agent for management of anthracnose disease of chilli caused by Colletotrichum gloeosporioides. Mezeal (2014) revealed that $B$. subtilis was effective 
Table 1. Effect of B. subtilis strain VB1 on the incidence of wilt under glass house conditions (Kharif 2015)

\begin{tabular}{lcccc}
\hline Treatments & $\begin{array}{c}\text { Germination } \\
(\%)\end{array}$ & $\begin{array}{c}\text { Plant height } \\
(\mathrm{cm}) \\
60 \mathrm{DAS}\end{array}$ & $\begin{array}{c}\text { Wilt incidence } \\
(\%) \\
60 \mathrm{DAS}^{*}\end{array}$ & $\begin{array}{c}\text { Yield } \\
\left(\mathrm{g} \mathrm{pot}^{-1}\right)\end{array}$ \\
\hline ST with B. subtilis VB1 & $86.17^{\mathrm{c}}$ & $48.35^{\mathrm{c}}$ & $23.12^{\mathrm{bcd}}$ & $70.69^{\mathrm{b}}$ \\
SA with B. subtilis VB1 (Basal) & $76.06^{\mathrm{h}}$ & $49.32^{\mathrm{b}}$ & $24.12^{\mathrm{bc}}$ & $74.81^{\mathrm{b}}$ \\
ST + SA with B. subtilis VB1 (Basal) & $88.49^{\mathrm{a}}$ & $52.97^{\mathrm{a}}$ & $18.48^{\mathrm{cd}}$ & $76.70^{\mathrm{ab}}$ \\
ST + SA with B. subtilis VB1 (Basal \& top dressing) & $87.78^{\mathrm{b}}$ & $53.53^{\mathrm{a}}$ & $14.59^{\mathrm{e}}$ & $85.97^{\mathrm{a}}$ \\
ST with P. fluorescens Pf1 & $77.00^{\mathrm{g}}$ & $47.18^{\mathrm{c}}$ & $22.71^{\mathrm{bc}}$ & $72.49^{\mathrm{b}}$ \\
SA with P. fluorescens Pf1 (Basal) & $85.68^{\mathrm{d}}$ & $49.28^{\mathrm{b}}$ & $22.27^{\mathrm{b}}$ & $73.24^{\mathrm{b}}$ \\
ST + SA with P. fluorescens Pf1 (Basal) & $84.21^{\mathrm{e}}$ & $53.85^{\mathrm{a}}$ & $18.22^{\mathrm{cd}}$ & $79.36^{\mathrm{ab}}$ \\
ST + SA with P. fluorescens Pf1 (Basal \& top dressing) & $84.12^{\mathrm{e}}$ & $53.45^{\mathrm{a}}$ & $16.24^{\mathrm{de}}$ & $83.24^{\mathrm{a}}$ \\
ST with carbendazim 0.1\% & $78.92^{\mathrm{f}}$ & $46.66^{\mathrm{d}}$ & $24.27^{\mathrm{bcd}}$ & $75.07^{\mathrm{b}}$ \\
ST + SA with carbendazim 0.1\% & $85.01^{\mathrm{d}}$ & $49.23^{\mathrm{b}}$ & $21.22^{\mathrm{cd}}$ & $77.20^{\mathrm{ab}}$ \\
Control & $77.57^{\mathrm{g}}$ & $47.29^{\mathrm{c}}$ & $32.68^{\mathrm{a}}$ & $48.67^{\mathrm{c}}$ \\
\hline
\end{tabular}

ST=Seed treatment @10 $\mathrm{g} \mathrm{kg}^{-1}$ of seeds; SA=Soil application @2.5 kg ha-1 ; ${ }^{*}$ DAS=Days After Sowing *Values are mean of three replications.

In a column, means followed by a common letter are not significantly different at the $5 \%$ level by DMRT.

Table 2. Effect of B. subtilis strain VB1 on the incidence of wilt under glass house conditions (Rabi 2015)

\begin{tabular}{lcccc}
\hline Treatments & $\begin{array}{c}\text { Germination } \\
(\%)\end{array}$ & $\begin{array}{c}\text { Plant height } \\
(\mathrm{cm}) \\
60 \mathrm{DAS}\end{array}$ & $\begin{array}{c}\text { Wilt incidence } \\
(\%) \\
60 \mathrm{DAS}^{*}\end{array}$ & $\begin{array}{c}\text { Yield } \\
\left(\mathrm{g} \mathrm{pot}^{-1}\right)\end{array}$ \\
\hline ST with B. subtilis VB1 & $85.61^{\mathrm{c}}$ & $48.16^{\mathrm{c}}$ & $23.91^{\mathrm{bcd}}$ & $70.10^{\mathrm{b}}$ \\
SA with B. subtilis VB1 (Basal) & $78.12^{\mathrm{f}}$ & $48.98^{\mathrm{c}}$ & $21.80^{\mathrm{bc}}$ & $75.18^{\mathrm{b}}$ \\
ST + SA with B. subtilis VB1 (Basal) & $87.97^{\mathrm{a}}$ & $53.76^{\mathrm{b}}$ & $16.57^{\mathrm{cd}}$ & $76.83^{\mathrm{ab}}$ \\
ST + SA with B. subtilis VB1 (Basal \& top dressing) & $87.78^{\mathrm{a}}$ & $53.81^{\mathrm{b}}$ & $12.85^{\mathrm{e}}$ & $83.58^{\mathrm{a}}$ \\
ST with P. fluorescens Pf1 & $75.00^{\mathrm{g}}$ & $47.03^{\mathrm{d}}$ & $21.55^{\mathrm{bc}}$ & $72.10^{\mathrm{b}}$ \\
SA with P. fluorescens Pf1 (Basal) & $87.72^{\mathrm{a}}$ & $48.81^{\mathrm{c}}$ & $18.07^{\mathrm{b}}$ & $72.80^{\mathrm{b}}$ \\
ST + SA with P. fluorescens Pf1 (Basal) & $85.56^{\mathrm{c}}$ & $54.16^{\mathrm{a}}$ & $15.87^{\mathrm{cd}}$ & $79.85^{\mathrm{ab}}$ \\
ST + SA with P. fluorescens Pf1 (Basal \& top dressing) & $82.12^{\mathrm{d}}$ & $54.10^{\mathrm{a}}$ & $13.16^{\mathrm{de}}$ & $80.80^{\mathrm{a}}$ \\
ST with carbendazim 0.1\% & $79.18^{\mathrm{e}}$ & $46.78^{\mathrm{e}}$ & $25.98^{\mathrm{bcd}}$ & $74.98^{\mathrm{b}}$ \\
ST + SA with carbendazim 0.1\% & $86.02^{\mathrm{b}}$ & $48.83^{\mathrm{c}}$ & $22.10^{\mathrm{cd}}$ & $75.85^{\mathrm{ab}}$ \\
Control & $79.14^{\mathrm{e}}$ & $47.03^{\mathrm{d}}$ & $29.81^{\mathrm{a}}$ & $46.89^{\mathrm{c}}$ \\
\hline
\end{tabular}

ST=Seed treatment @10 $\mathrm{g} \mathrm{kg}^{-1}$ of seeds; SA=Soil application @2.5 kg ha-1; *DAS=Days After Sowing *Values are mean of three replications.

In a column, means followed by a common letter are not significantly different at the $5 \%$ level by DMRT. 
Table 3. Effect of B. subtilis strain VB1 on the incidence of wilt under glass house conditions (Pooled mean of 2 trials)

Treatments

Germination Plant height Wilt incidence Yield

$(\%) \quad(\mathrm{cm}) \quad(\%) \quad\left(\mathrm{g} \mathrm{pot}^{-1}\right)$

60 DAS* $^{*} \quad 60$ DAS* $^{*}$

\begin{tabular}{lllll}
\hline ST with B. subtilis VB1 & $86.17^{\mathrm{c}}$ & $48.35^{\mathrm{c}}$ & $23.12^{\mathrm{bcd}}$ & $70.69^{\mathrm{b}}$ \\
SA with B. subtilis VB1 (Basal) & $76.06^{\mathrm{h}}$ & $49.32^{\mathrm{b}}$ & $24.12^{\mathrm{bc}}$ & $74.81^{\mathrm{b}}$ \\
ST + SA with B. subtilis VB1 (Basal) & $88.49^{\mathrm{a}}$ & $52.97^{\mathrm{a}}$ & $18.48^{\mathrm{cd}}$ & $76.70^{\mathrm{ab}}$ \\
ST + SA with B. subtilis VB1 (Basal \& top dressing) & $87.78^{\mathrm{b}}$ & $53.53^{\mathrm{a}}$ & $14.59^{\mathrm{e}}$ & $85.97^{\mathrm{a}}$ \\
ST with P. fluorescens Pf1 & $77.00^{\mathrm{g}}$ & $47.18^{\mathrm{c}}$ & $22.71^{\mathrm{bc}}$ & $72.49^{\mathrm{b}}$ \\
SA with P. fluorescens Pf1 (Basal) & $85.68^{\mathrm{d}}$ & $49.28^{\mathrm{b}}$ & $22.27^{\mathrm{b}}$ & $73.24^{\mathrm{b}}$ \\
ST + SA with P. fluorescens Pf1 (Basal) & $84.21^{\mathrm{e}}$ & $53.85^{\mathrm{a}}$ & $18.22^{\mathrm{cd}}$ & $79.36^{\mathrm{ab}}$ \\
ST + SA with P. fluorescens Pf1(Basal \& top dressing) & $84.12^{\mathrm{e}}$ & $53.45^{\mathrm{a}}$ & $16.24^{\mathrm{de}}$ & $83.24^{\mathrm{a}}$ \\
ST with carbendazim 0.1\% & $84.12^{\mathrm{e}}$ & $53.45^{\mathrm{a}}$ & $16.24^{\mathrm{de}}$ & $83.24^{\mathrm{a}}$ \\
ST + SA with carbendazim 0.1\% & $85.01^{\mathrm{d}}$ & $49.23^{\mathrm{b}}$ & $21.22^{\mathrm{cd}}$ & $77.20^{\mathrm{ab}}$ \\
Control & $77.57^{\mathrm{g}}$ & $47.29^{\mathrm{c}}$ & $32.68^{\mathrm{a}}$ & $48.67^{\mathrm{c}}$ \\
\hline
\end{tabular}

ST=Seed treatment @10 $\mathrm{g} \mathrm{kg}^{-1}$ of seeds; SA=Soil application @2.5 kg ha-1; *DAS=Days After Sowing *Values are mean of three replications.

In a column, means followed by a common letter are not significantly different at the $5 \%$ level by DMRT.

against Rhizoctonia solani and F. oxysporum causing wilt disease in tomato. Lin et al. (1990) reported that $B$. subtilis inhibited the growth of Fusarium oxysporum f. sp. niveum (watermelon wilt) under in vitro and pot culture studies.

In the present study, application of bio control agents at different stages of crop as seed treatment and soil application at 30 and 45 DAS, supported the population load of antagonistic organisms in the rhizosphere region, thereby suppressing the pathogen load and disease incidence.

\section{References}

Ashwini N \& Srividya S 2014 Potentiality of Bacillus subtilis as biocontrol agent for management of anthracnose disease of chilli caused by Colletotrichum gloeosporioides OGC1. Biotech. 4: 127-136.

Balabel N M, Messiha N A \& Farag N S 2013 New findings on biological control trials of potato brown rot with antagonistic strains of
Bacillus circulans in Egypt. Plant Pathol. J. 12: 11.

Das A M 1971 Studies on stem gall disease of coriander incited by Protomyces macrosporus. Abstracts of papers presented at the second international symposium on plant pathology conducted during $27^{\text {th }}$ Jan to $3^{\text {rd }}$ Feb, 1971 at IARI, New Delhi, pp.80-81.

Dennis C \& Webster J 1971 Antagonistic properties of species group of Trichoderma production of non-volatile antibiotics. Transactions of the British Mycol. Soci. 57: 25-39.

Huang X, Zhang N, Yong X, Yang X \& Shen Q 2012 Biocontrol of Rhizoctonia solani damping-off disease in cucumber with Bacillus pumilus SQR-N43. Microbiol. Res. 167: 135-143.

ICAR 1953 Scheme on studies in the wilt disease of coriander in the Madhya Bharat, New Delhi.

Lin F C, Zhang B X \& Ge Q X 1990 Effects of antagonisti by three isolates of Bacillus subtilis on conidia of Fusarium oxysporum f.sp. 
niveum. Acta Agriculturae Universitatis Zhejian 16: 235-240.

Liu B, Qiao H, Huang L, Buchenauer H, Han Q, Kang Z \& Gong Y 2009 Biological control of take-all in wheat by endophytic Bacillus subtilis E1R-j and potential mode of action. Biol. Control 49: 277-285.

Mezeal I A 2014 Study biocontrol efficacy of pseudomonas fluorescens and Bacillus subtilis against Rhizoctonia solani and Fusarium oxysporum causing disease in tomato. Indian J. Fundamental Appl. Life Sci. 4: 175-183.

Peng D, Li S, Wang J, Chen C \& Zhou M 2014 Integrated biological and chemical control of rice sheath blight by Bacillus subtilis NJ 18 and jinggangmycin. Pest Manag. Sci. 70: 258-263.

Prakasam V, Vedamuthu P G B, Khader M A \& Jeyarajan R 1987 Screening coriander lines for wilt resistance. South Indian Hort. 35: 258-259.

Rajan F S, Vedamuthu P G B, Khader M K \& Jeyarajan R 1990 Screening coriander lines against grain mould disease. South Indian Hort. 38: 168-169.

Saha D, Purkayastha G D, Ghosh A, Isha M \& Saha A 2012 Isolation and characterization of two new Bacillus subtilis strains from the rhizosphere of eggplant as potential biocontrol agents. J. Plant Pathol. 94: 109118.

Srivastava U S 1972 Effect of interaction of factors on wilt of coriander caused by Fusarium oxysporum f. corianderii. Indian J. Agri. Sci. 42: 618-620.

Vidhyasekaran P \& Muthamilan M 1995 Development of formulations of Pseudomonas fluorescens for control of chickpea wilt. Plant Dis. 79: 782-786. 